\title{
幅変化にフェルミ関数を用いた不均一伝送線路周期構造フィル夕
}

\author{
正 員 松下 健治* 非会員 福田 誠* \\ 正員 浜中 宏一*
}

\section{Filter Circuit with Periodically Arranged Nonuniform Microstriplines Having Linewidths Determined by Fermi-Dirac Distribution Function}

Kenji Matsushita*, Member, Makoto Fukuda*, Non-member, Kouich Hamanaka*, Member

In this paper, a broadband bandstop filter consisting of periodically arranged nonuniform microstriplines is presented. The Fermi-Dirac distribution function is used for determining the linewidth of the microstriplines. The advantage of using this function is that the shape of the transmission line can be varied by varying a parameter of the function. Calculation and measurement results showed that the filter provides frequency characteristics between those obtained by using a step function and those obtained by using a linear function. As a result, broadband bandstop filter with a center frequency of $5.25 \mathrm{GHz}$ and bandwidth of $3.58 \mathrm{GHz}$ was obtained.

キーワード : バンドストップフィルタ, フェルミ・ディラック関数, 周期構造, 不均一伝送線路

Keywords: bandstop filter, Fermi-Dirac distribution function, periodic structure, nonuniform microstripline.

\section{1. まえがき}

不均一伝送線路はプリント基板や IC 内部の配線などに 多く含まれており，その伝送特性を知ることによって，よ り正確な回路特性の解析が可能となる。そのため現在にお いても，その伝送特性を得るための新しい解析方法が提案 されている(1)。一方, 周期構造フィルタについても, 古く は導波管を用いたフィル夕などが知られており，各種フィ ル夕が実現されている。そこで，これらのシミュレーショ ン技術を一次元の周期構造をもつフィルタ回路の解析に応 用し，広帯域の特性を持つバンドストップフィルタを設計 することを目的として，これまでに一次関数を用いて線路 形状を変化させた不均一線路によるフイル夕について研究 を行ってきた ${ }^{(2)}$ 。しかし，この形状のフィルタでは，不均 一線路の広端の線路幅 $w_{1}$ と狭端の線路幅 $w_{2}$ の比（特性 インピーダンス比）を変化させることによってのみフィル 夕の特性が変化し, その比の值が実現可能である範囲は使 用する基板の物理的寸法や誘電率によって制約を受ける。 この問題を解決するために，本研究では，線路幅を決定す る関数としてフェルミ・ディラック関数を採用し, 特性イ ンピーダンス比だけではなく，線路の形状を制御するパラ メータを導入した。これによって帯域幅と減衰率について 設計の自由度が増すことが期待される。

\footnotetext{
* 千歳科学技術大学

干 066-8655 北海道千歳市美々 758-65

Chitose Institute of Science and Technology

Bibi 758-65, Chitose, Hokkaido 066-8655
}

\section{2. 設計}

周期構造フィルタは，いわゆるブラッグ反射構造を有し ており，特定の周波数において入射電力を反射するバンド ストップフィルタとして動作する。このフィルタの周期 $\Lambda$ とストップバンドの中心周波数 $f_{m}$ との関係は, 実効比誘 電率 $\epsilon_{e f f}$ と真空中の光速 $c_{0}$ を用いて, 次のように表すこ とができる。

$$
\Lambda=\frac{c_{0}}{2 f_{m} \sqrt{\epsilon_{e f f}}}
$$

回路の製作に使用した基板（松下電工 R4726）は比誘電率 $\epsilon_{r}=3.4$, 基板厚 $h=1.2 \mathrm{~mm}$, 導体厚 $t=18 \mu \mathrm{m}$ であるか ら， $f_{m}$ を $5.2 \mathrm{GHz}$ と設定した場合， $\Lambda$ は $17.6 \mathrm{~mm}$ となる。 また，線路の幅を決定する関数 $w_{i}(x)$ を，フェルミ・ディ ラック関数を使って次のように設定して数值解析を行った。

$$
\begin{aligned}
& w_{i}(x)=\frac{1}{2}\left(\frac{w_{d}(x)}{w_{d}(0)}+1\right)\left(w_{1}-w_{2}\right)+w_{2}, \cdots \\
& w_{d}(x)=\frac{1}{1+\exp \left[a\left\{\frac{\ln 99}{\Lambda / 4} x-\ln 99\right\}\right]} \cdots \cdots \cdots
\end{aligned}
$$

ここで, $x$ は伝送方向の座標を, $a$ は線路の形状を決定す るパラメータをそれぞれ表す。この $a$ を変化させることに よって, フィルタのパターン形状を一次関数からステップ 関数まで連続的に変化させることができるので，伝送特性 である $S_{21}$ の周波数特性についても, 双方のパターン形状 をもつフィルタの間で連続的に変化させることができる。 


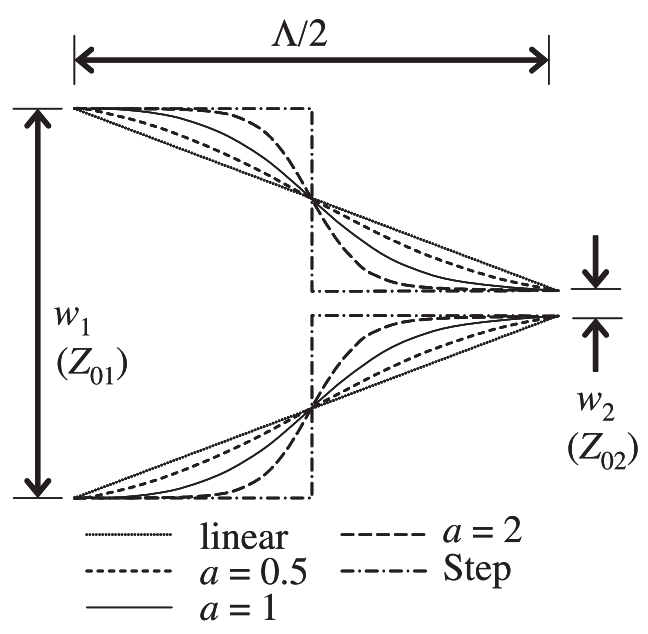

Fig. 1. Shapes of nonuniform microstriplines described in equations (2)-(3).

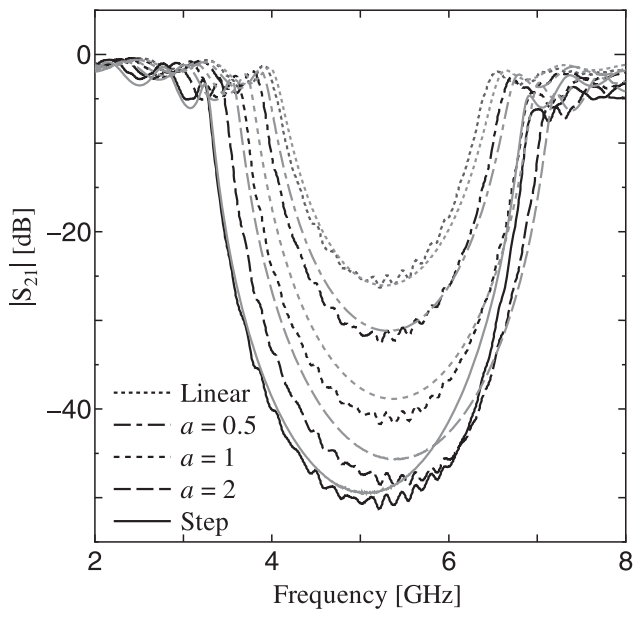

Fig. 2. Frequency characteristics at various values of $a\left(p=6, w_{1}=2.65 \mathrm{~mm}, w_{2}=0.2 \mathrm{~mm}\right)$.

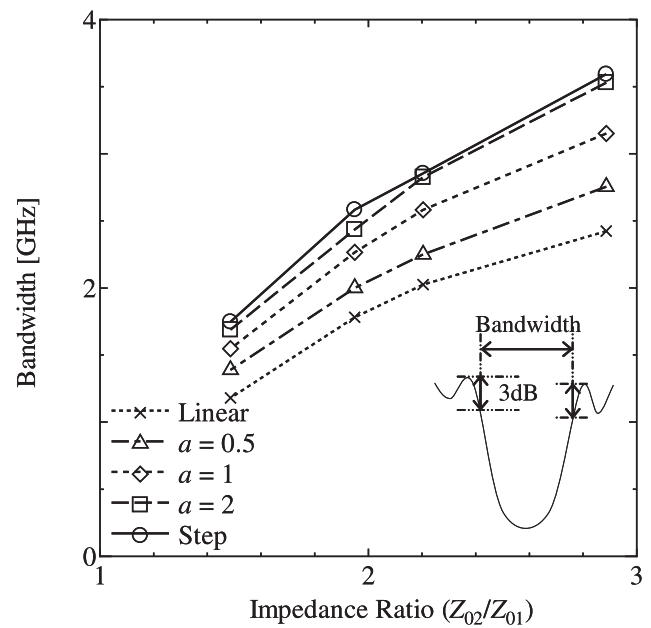

Fig. 3. Measured bandwidth for the filters versus characteristic impedance ratio for various values of the parameter $a\left(f_{m}=5.2 \mathrm{GHz}, w_{1}=2.7 \mathrm{~mm}\right)$.

Fig. 1 にフェルミ・ディラック関数のパラメータを変化さ せたときの不均一伝送線路の半周期分の形状変化を示す。

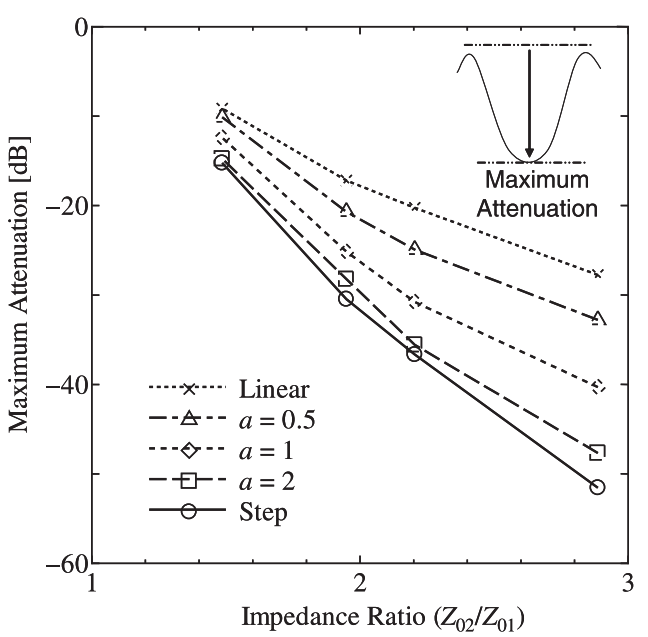

Fig. 4. Measured maximum attenuation for the filters versus characteristic impedance ratio for various values of the parameter $a\left(f_{m}=5.2 \mathrm{GHz}\right.$, $w_{1}=2.7 \mathrm{~mm}$ ).

\section{3. 計算と測定}

パラメータ $a$ に対する伝送特性の変化について, 計算と 測定を行った。伝送特性を計算する方法 ${ }^{(2)}$ は, 不均一伝送 線路を微小な伝送線路に分割し，それぞれの $\mathrm{ABCD}$ 行列を 乗算して一周期 $\Lambda$ 分の特性を計算する。それを周期数 $p$ (こ こでは 6 とした) だけ乗算することによってフィル夕全体 の特性を求め, 最後に $\mathrm{S}$ 行列に変換した。測定にはべクト ルネットワークアナライザ（アドバンテスト R3767CG）を 用いた。パラメータ $a$ に対する周波数特性の変化を Fig. 2 に示す。黒色の線が測定結果であり，灰色の線が計算結果 である。中心周波数 $5.25 \mathrm{GHz}$ (設計值 $5.2 \mathrm{GHz}$ ) で, 带域 幅が最大で $3.58 \mathrm{GHz}$ のバンドストップフィルタを得るこ とができ，また，パラメータ $a$ を変化させることによって， 一次関数形状とステップ関数形状をもつフィルタの間の特 性を連続的に実現できる事を確認した。さらに, 特性イン ピーダンス比とパラメータ $a$ を独立に変化させることによっ て, Fig. 3, Fig. 4, のようにフィルタの带域幅, 最大減衰 率の範囲を広げることができた。

\section{4. まとめ}

伝送線路がフェルミ・ディラック関数に従って変化する不 均一伝送線路を用いた周期構造を持つバンドストップフィ ル夕について，その特性を数值解析するとともに実際に回 路を作製した。その結果, 関数内のパラメー夕を操作する 事によってパターン形状とフイルタの带域幅と減衰率を連 続的に変化させることに成功した。

(平成 21 年 7 月 2 日受付，平成 21 年 8 月 18 日再受付)

$$
\text { 文献 }
$$

(1) M.H. Eghlidi, K. Mehrany, and B. Rashidian: IEEE Trans. MTTs-54, No.12, (2006-12)

(2) K. Matsushita and M. Fukuda: IEEJ Trans. Electrical and Electronic Engineering, Vol.5, No.1, (to be published) 